\title{
Identification and characterization of human papillomavirus DNA sequences in Italian breast cancer patients by PCR and line probe assay reverse hybridization
}

\author{
DEBORA DUÒ ${ }^{1 *}$, CHIARA GHIMENTI ${ }^{2 *}$, PAOLA MIGLIORA $^{1}$, MARIA CRISTINA PAVANELLI $^{1}$, \\ LUCA MASTRACCI $^{3}$ and GIOVANNI ANGELI ${ }^{1,2}$ \\ ${ }^{1}$ Unit of Pathological Anatomy, S. Andrea Hospital, Vercelli; ${ }^{2}$ Fondazione 'Edo ed Elvo Tempia Valenta per la lotta \\ contro i tumori - ONLUS', Biella; ${ }^{3}$ DICMI, Pathological Anatomy Section, University of Genoa, Genoa, Italy
}

Received May 12, 2008; Accepted July 18, 2008

DOI: $10.3892 / \mathrm{mmr} 00000011$

\begin{abstract}
Human papillomavirus (HPV) infection is known to play a fundamental role in cervical and other ano-genital human cancers. The recent identification of HPVs in human breast tumors and the immortalization of normal breast cancer cells by HPV high risk types 16 and 18 suggest that the virus could be implicated in the pathogenesis of human mammary tumors. In this study, we investigated the presence of high and low risk HPV genotypes in 30 human breast cancers of different histotypes by PCR with specific HPV primers (MY09/MY11 and $\mathrm{GP}^{+} / \mathrm{GP}^{+}$) and by line probe assay (LiPA) reverse hybridization. Since the only positive case (untypable $\mathrm{HPVX}^{+}$) was a papillary breast carcinoma, a rare tumor variant, we analyzed a further cohort of 32 papillary cancers and found one additional HPV DNA-positive case $\left(\mathrm{HPV}^{\circ} 6^{+}\right)$. Our results suggest that HPV infection is not significant in mammary tumorigenesis, with the exception of particular tumor histotypes, such as papillary cancer.
\end{abstract}

\section{Introduction}

Breast cancer is a malignant neoplasia with a high incidence in women in most countries of the western world (1). The aetiology of breast cancer remains largely unknown. Although many risk factors have been associated with the development

Correspondence to: Dr Giovanni Angeli, Unit of Pathological Anatomy, S. Andrea Hospital, ASL11, Corso M. Abbiate 21, I-13100 Vercelli, Italy

E-mail: laboratorio@fondoedotempia.it

${ }^{*}$ Contributed equally

Abbreviations: HPV, human papillomavirus; PCR, polymerase chain reaction; LiPA, line probe assay

Key words: human papillomavirus infection, breast tumor, breast papillary carcinoma of the disease, including hormone status, cigarette smoking and alcohol consumption, the molecular mechanisms related to breast carcinogenesis remain poorly understood (2). Hereditary factors are known to be responsible for only approximately $5-10 \%$ of all breast tumors $(3,4)$. The identification of other factors implicated in sporadic breast carcinoma onset is therefore of great interest.

More than 100 genotypes of human papillomavirus (HPV) have been identified, although only a subset of these have carcinogenic potential (5). HPV selectively infects the epithelium of the skin and mucous membranes. Specific HPV types are associated with squamous cell carcinoma, adenocarcinoma and dysplasias of the cervix, penis, anus, vagina and vulva (6). Using current technology, HPV DNA can be detected in 95-100\% of cervical cancer specimens, and is regarded as a prerequisite for disease occurence $(7,8)$.

The hypothesis that HPV might play a role in breast carcinogenesis originated from an experimental system in which a human mammary cell line was immortalized after transfection with the full-length HPV type 16 or 18 genome (9). However, the presence of HPV in malignant tumors of the breast has been controversial.

Di Lonardo et al were the first to report a relationship between HPV and breast cancer, demonstrating HPV16 DNA in $29.4 \%$ of 17 breast carcinomas analyzed by PCR (10).

The presence of HPV DNA has been found in various percentages in different studies. Damin et al detected HPV16 and/or HPV 18 DNA in approximately $25 \%$ of breast carcinomas, but none in benign breast cancer specimens (11). Similar results were obtained for HPV33 DNA in Chinese and Japanese patients with breast cancer $(12,13)$, and in a Greek study (14). HPV18 DNA was demonstrated in $48 \%$ of malignant mammary tumors from Australian women (15).

Notably, a Norwegian study on women with a history of high-grade cervical intraepithelial neoplasia (CINIII) and breast carcinoma as a second primary neoplasia showed the presence of HPV16 DNA in 46\% of breast cancer specimens, suggesting that HPV-associated cervical neoplasia might be the original site of HPV infection from which the virus is transported to the breast (all HPV16-positive breast cancers were HPV16-positive in their corresponding CINIII lesions) (16). Moreover, in another study, the axillary lymph nodes of 
patients with both HPV-positive cervical and breast cancer showed the presence of the same HPV genotype, suggesting that HPV may be transported by the bloodstream (17).

In contrast, other researchers have failed to demonstrate the presence of HPV DNA in samples of breast carcinoma, even when the same methods of detection were applied (18-22). Moreover, a high percentage of low risk genotype HPV DNA was present not only in breast tumors, but also in normal tissue $(23,24)$.

This study verified the presence and characterized the specific genotype of HPV DNA in breast carcinomas from Italian patients, with the aim of assessing the role of HPV infection in mammary tumorigenesis.

\section{Materials and methods}

Specimens. Thirty formalin-fixed paraffin-embedded samples of breast cancer were obtained from the archives of the Unit of Pathological Anatomy of S. Andrea Hospital in Vercelli. These specimens included various types of breast carcinoma randomly selected for patient age, grade and receptor expression (Table I). Afterwards, an additional 7 and 25 formalinfixed paraffin-embedded samples of papillary breast cancer were obtained from the archives of the Unit of Pathological Anatomy of S. Andrea Hospital and from the archives of the Unit of Pathological Anatomy of S. Martino Hospital in Genoa, respectively.

H\&E-stained slides from the blocks were analyzed for the presence of tumor tissue, histotype and grading by two pathologists (P.M. and G.A.). Two or three $10-\mu \mathrm{m}$ sections from each sample were collected in sterile tubes. DNA was extracted using the High Pure PCR Template Preparation kit (Roche Molecular Biochemicals) according to the manufacturer's protocol.

PCR analysis. Genomic DNA (50-100 $\mu \mathrm{g})$ of each sample was amplified by PCR. The quality of the DNA obtained from the fixed samples was evaluated by amplification with specific primers of a 248-bp fragment of the housekeeping B-globin gene. The presence of HPV DNA sequences was verified by amplification with two specific sets of primers, MY09/MY11 and $\mathrm{GP}^{+} / \mathrm{GP}^{+}$, generating a 450 -bp and a 150 -bp fragment, respectively (25).

ß-globin PCR was carried out in a reaction volume of $50 \mu \mathrm{l}$ containing $100 \mathrm{ng}$ of genomic DNA, $50 \mathrm{mM} \mathrm{KCl}, 10 \mathrm{mM}$ Tris-HCl pH 8.3, $2 \mathrm{mM} \mathrm{MgCl} 2,200 \mu \mathrm{M}$ dNTPs, $0.5 \mu \mathrm{M}$ of each primer and $0.05 \mathrm{U} / \mu 1 \mathrm{Taq}$ polymerase. MY09/MY11 PCR was carried out in a reaction volume of $50 \mu 1$ containing $100 \mathrm{ng}$ of genomic DNA, $50 \mathrm{mM} \mathrm{KCl}, 10 \mathrm{mM}$ Tris- $\mathrm{HCl} \mathrm{pH} 8.3$, $1 \mathrm{mM} \mathrm{MgCl}_{2}, 200 \mu \mathrm{M}$ dNTPs, $1 \mu \mathrm{M}$ each primer and $0.05 \mathrm{U} /$ $\mu 1 \mathrm{Taq}$ polymerase. $\mathrm{GP}^{+} / \mathrm{GP}^{+} \mathrm{PCR}$ was carried out in a reaction volume of $50 \mu 1$ containing $100 \mathrm{ng}$ of genomic DNA, $50 \mathrm{mM} \mathrm{KCl}, 10 \mathrm{mM}$ Tris-HCl pH 8.3,3.5 mM MgCl $2,200 \mu \mathrm{M}$ dNTPs, $1 \mu \mathrm{M}$ each primer and $0.05 \mathrm{U} / \mu 1$ Taq polymerase. Amplification for B-globin and MY09/MY11 consisted of an initial denaturation stage at $95^{\circ} \mathrm{C}$ for $10 \mathrm{~min}$ followed by 40 cycles of $2 \mathrm{~min}$ at $95^{\circ} \mathrm{C}, 2 \mathrm{~min}$ at $57^{\circ} \mathrm{C}$ and $2 \mathrm{~min}$ at $72^{\circ} \mathrm{C}$, with a final extension at $72^{\circ} \mathrm{C}$ for $7 \mathrm{~min}$. For $\mathrm{GP}^{+} / \mathrm{GP}^{+}$, an initial denaturation at $94^{\circ} \mathrm{C}$ for $10 \mathrm{~min}$ followed by 40 cycles of $1 \mathrm{~min}$ at $94^{\circ} \mathrm{C}, 2 \mathrm{~min}$ at $40^{\circ} \mathrm{C}$ and $90 \mathrm{sec}$ at $72^{\circ} \mathrm{C}$, with a final extension at $72^{\circ} \mathrm{C}$ for $7 \mathrm{~min}$, was used. After amplification, PCR products were separated by electrophoresis on $3 \%$ agarose gel stained by ethidium bromide.

HPV genotyping. DNA samples showing positivity for MY09/ MY11 and/or $\mathrm{GP}^{+} / \mathrm{GP}^{+}$were analyzed by the INNO-line probe assay (LiPA) HPV Genotyping v2 amp kit and the INNO-LiPA HPV Genotyping v2 kit (Innogenetics) according to the manufacturer's protocol in order to identify the specific HPV genotype infecting the sample. Briefly, the INNO-LiPA HPV Genotyping v2 amp kit is designed to amplify a part of the L1 region of the HPV genome using PCR amplification with biotinylated primers. Use of this kit is based on the reverse hybridization principle, where denaturated biotinylated amplicons are hybridized with specific oligonucleotide probes, which are immobilized as parallel lines on membrane strips. After hybridization and stringent washing, streptavidineconjugated alkaline phosphatase is added and binds to any biotinylated hybrid previously formed. Incubation with BCIP/ NBT chromogen yields a purple precipitate, and the results can be visually interpreted.

\section{Results}

PCR analysis and HPV genotyping. Of the 30 DNA samples extracted from paraffin-embedded breast cancers of different histotypes, 24 were positive for $\beta$-globin amplification and were consequently considered suitable for HPV PCR analysis. One of the 24 DNA samples showed positivity for MY09/ MY11 and $\mathrm{GP}^{+} / \mathrm{GP}^{+}$amplification. HPV genotyping as above only showed the presence of generic HPV DNA, and none of a specific virus genotype (Fig. 1A).

Notably, the HPV-positive DNA sample was extracted from a rare breast cancer variant, papillary breast cancer. For this reason, we decided to collect and analyze a further cohort of 32 formalin-fixed paraffin-embedded samples of papillary breast cancer in order to verify whether HPV infection is significantly related to the pathogenesis of this specific type of tumor.

Of the 32 DNA samples extracted from the cohort of papillary breast cancer specimens, 28 were positive for $ß$-globin amplification and were consequently considered suitable for HPV PCR analysis. One of the 28 DNA samples exhibited positivity for MY09/MY11 and GP5+/GP6 ${ }^{+}$amplification. HPV genotyping as above revealed the presence of the specific high-risk HPV66 virus genotype (Fig. 1B).

To evaluate the reliability of MY09/MY11 and GP5+/ $\mathrm{GP6}^{+}$PCR, using the INNO-LiPA HPV Genotyping v2 kit we analyzed an additional ten breast tumors randomly selected from among the MY09/MY11 and $\mathrm{GP}^{+} / \mathrm{GP}^{+}$PCR negative cohort. This yielded the absence of HPV DNA by reverse hybridization as well (data not shown).

To sum up, 2 of 52 (4\%) breast cancer specimens showed the presence of HPV infection. Both of these samples were of papillary breast cancer.

\section{Discussion}

The relationship between viruses and mammary tumors is known from the induction of mammary cancer in mice with 
Table I. Histopathological data of analyzed breast cancer patients.

\begin{tabular}{|c|c|c|c|c|c|c|c|c|}
\hline Patient & Age & Tumor & Grade & $\begin{array}{c}\text { Estrogen } \\
\text { receptor }(\%)\end{array}$ & $\begin{array}{l}\text { Progesterone } \\
\text { receptor }(\%)\end{array}$ & $\begin{array}{c}\mathrm{p} 53 \\
\text { expression }(\%)\end{array}$ & $\begin{array}{c}\text { Mib-1/Ki-67 } \\
\text { expression (\%) }\end{array}$ & $\begin{array}{c}\text { c-erbB2 } \\
\text { expression }(\%)\end{array}$ \\
\hline $1 / 06$ & 50 & IDC & 3 & $<5$ & $<5$ & $<5$ & 25 & \\
\hline $2 / 06$ & 42 & IDC & 2 & 50 & $<5$ & 5 & 20 & 100 \\
\hline $3 / 06$ & 57 & IPC & 1 & 60 & 20 & & $<5$ & \\
\hline $4 / 06$ & 71 & ILC & & 60 & 25 & Negative & 30 & \\
\hline $5 / 06$ & 48 & IDC $80 \%$ IntraDC $20 \%$ & 1 & 70 & 10 & Negative & $<10$ & \\
\hline $6 / 06$ & 50 & IDC $80 \%$ IntraDC $20 \%$ & $2 ; 3$ & 20 & Negative & Negative & 20 & 90 \\
\hline $7 / 06$ & 69 & ILC & 2 & 90 & 30 & Negative & 10 & 30 \\
\hline $8 / 06$ & 48 & ILC $80 \%$ in situ LC $20 \%$ & 1 & 90 & 20 & Negative & 12 & \\
\hline $9 / 06$ & 36 & ILC & 2 & 60 & 60 & & 5 & Weak \\
\hline $10 / 06$ & 64 & IPC & 2 & 80 & Negative & & 5 & \\
\hline $11 / 06$ & 45 & ILC & 2 & 90 & 90 & 10 & 15 & Diffuse \\
\hline $12 / 06$ & 44 & IDC & 2 & 80 & 5 & 10 & 10 & Weak \\
\hline $13 / 06$ & 44 & IDC & 2 & 50 & 80 & 1 & 30 & Weak \\
\hline $14 / 06$ & 52 & ITLC & 1 & 80 & 60 & $<5$ & 5 & Weak \\
\hline $15 / 06$ & 55 & IDC & 3 & 100 & 100 & 5 & 30 & Weak \\
\hline $16 / 06$ & 58 & IDC & 2 & 100 & $<10$ & $<5$ & $<10$ & Weak \\
\hline $17 / 06$ & 37 & IDC & 2 & 80 & 15 & Negative & 10 & \\
\hline $18 / 06$ & 57 & IDC & 3 & Negative & Negative & 80 & 30 & Weak \\
\hline $19 / 06$ & 50 & IDC & 3 & 80 & Negative & Negative & 40 & Intense/diffuse \\
\hline $20 / 06$ & 57 & ITLB & 1 & 100 & 100 & & 10 & Incomplete \\
\hline $21 / 06$ & 57 & IDC & 3 & 90 & 80 & 10 & 30 & Intense/diffuse \\
\hline $22 / 06$ & 42 & IDC & 3 & $<5$ & $<5$ & 10 & 20 & Weak \\
\hline $23 / 06$ & 58 & IDC & 3 & Negative & Negative & Negative & 60 & Weak \\
\hline $24 / 06$ & 54 & IDC & 3 & 90 & Negative & Negative & 20 & Weak \\
\hline $25 / 06$ & 44 & IDC & 2 & Negative & Negative & & 15 & Intense/diffuse \\
\hline $26 / 06$ & 65 & IDC & 2 & 80 & 80 & & $<5$ & \\
\hline $27 / 06$ & 50 & IDC & 1 & 100 & 80 & & & Incomplete \\
\hline $28 / 06$ & 60 & IDC & 3 & 90 & 50 & & 40 & Weak \\
\hline $29 / 06$ & 52 & IDC & 1 & 100 & 10 & $<5$ & 15 & Weak \\
\hline $30 / 06$ & 44 & IDC $60 \%$ IntraDC $40 \%$ & 2 & 80 & 80 & $<5$ & $<10$ & Weak \\
\hline
\end{tabular}

IDC, infiltrating ductal carcinoma; ILC, infiltrating lobular carcinoma; IPC, infiltrating papillary carcinoma; ITLC, infiltrating tubular-lobular carcinoma; IntraDC, intraductal carcinoma.

the mouse mammary tumor virus (MMTV) $(26,27)$. However, the data obtained from studies investigating the presence of viral sequences in cancer biopsies and cell lines have been controversial. A human equivalent of MMTV has been described in breast tumors, as well as in breast cancer cell lines (28). These results have been questioned and negated by others (29).

Human viral carcinogenesis is well established through studies that have demonstrated the relationship between cervical dysplasia, cancer, and HPVs (30). The suspicion that HPVs may also play a role in human breast cancer is based on the immortalization of normal human breast cells by HPV types 16 and 18 (9). However, data on the presence of HPV DNA in human mammary tumor biopsies are controversial (10-24).

In this study, out of 52 cases of breast cancer only two were found to be HPV DNA-positive. Both tumors were breast papillary carcinomas and showed the presence of untypable HPVX DNA and high risk HPV66 DNA, respectively.

We routinely use the INNO-LiPA HPV Genotyping v2 kit for HPV DNA analysis of cervical cancers, and were able to verify the robustness of the technique. Using the kit, we also analyzed an additional ten breast tumors randomly selected among the MY09/MY11 and GP5+/GP6 ${ }^{+}$PCR negative cohort in order to evaluate the reliability of MY09/MY11 and $\mathrm{GP}^{+} /$ GP6 ${ }^{+}$PCR. This yielded the absence of HPV DNA by reverse hybridization as well.

Our results suggest that HPV infection is not significant in mammary tumorigenesis, with the exception of particular tumor histotypes, such as papillary cancer. It has been suggested that HPVs may infect the epithelium of the nipple and the areola, and could be identified by recognizable histological features, as in HPV infection at other sites (23). The pathogenic mechanism involves the transfer of HPV in a 
A.

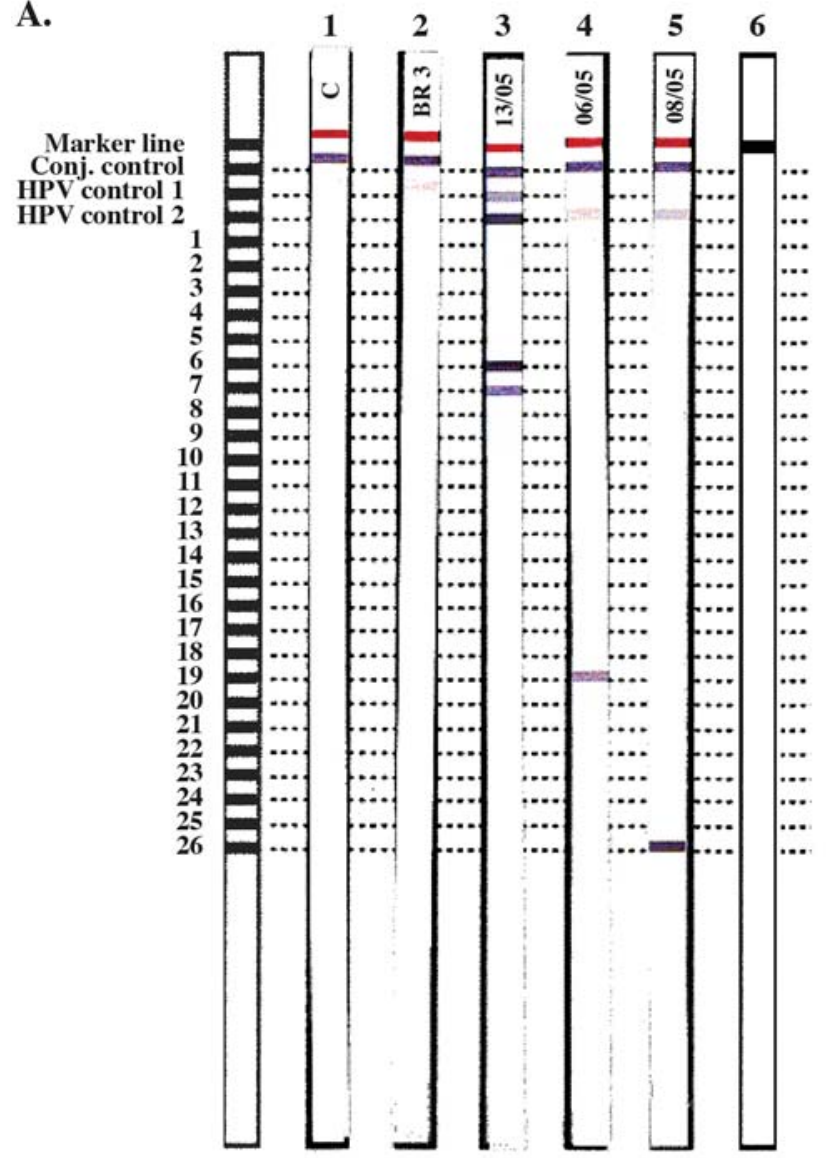

B.

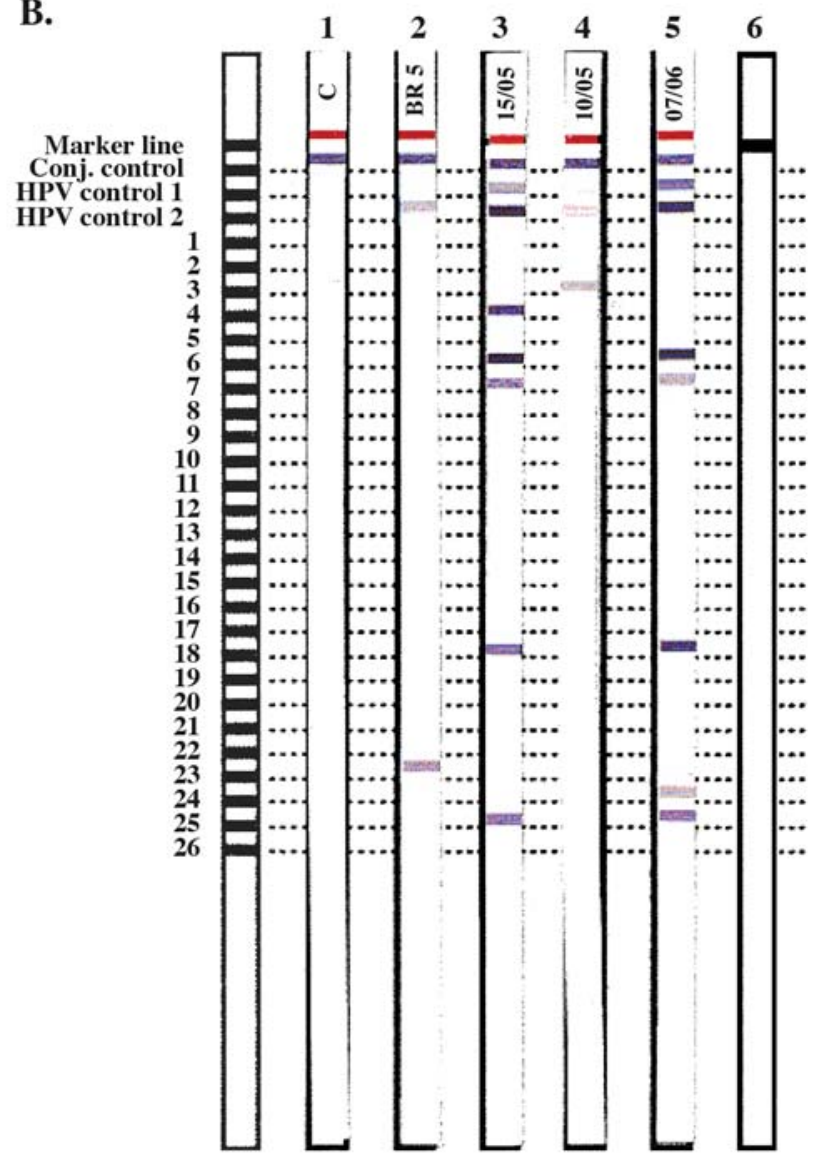

Figure 1. Reverse hybridization on INNO-LiPA strips. (A) Strip 1, negative control, no DNA; strip 2, HPV DNA- positive breast cancer (HPVX ${ }^{+}$); strips 3-5, HPVpositive controls (cervical tumors). (B) Strip 1, negative control, no DNA; strip 2, HPV DNA-positive breast cancer (HPV66 ${ }^{+}$; strips 3-5, HPV-positive controls (cervical tumors)

retrograde fashion via the nipple, areola, lactiferous ducts and sinuses (23).

Our data appear to be in accord with findings that low risk HPV is rarely identified in benign squamous papillomas of the mammary nipple (31). Moreover, other researchers have failed to demonstrate the presence of HPV DNA in samples of breast carcinoma (18-22). Differences in the prevalence of HPV infection in tumors of the breast could be due to the particular population analyzed. For example, in Japanese-Chinese cohorts, a prevalence of the HPV33 genotype $(12,13)$ has been demonstrated. This is in contrast to other countries, such as Australia, Austria and Brasil, where the presence of the HPV16 and HPV18 genotypes has primarily been found $(11,15,17)$.

\section{Acknowledgements}

We thank Innogenetics for the INNO-LiPA HPV Genotyping v2 kit for breast cancer sample characterization.

\section{References}

1. Parkin DM, Muir C and Whelan SL: Cancer incidence in five continents. International Agency for Research on Cancer Scientific Publications, Lyon, p957, 1992.

2. Brinton L, Lacey J Jr and Devesa SS: Epidemiology of breast cancer. In: Cancer of the Breast. Donegan WL and Spratt JS (eds). 5th edition, Saunders Elsevier Science, London, pp111-132, 2002.
3. Newman B, Mu H, Butler LM, Millikan RC, Moorman PG and King MC: Frequency of breast cancer attributable to BRCA1 in a population-base series of American women. JAMA 279: 915-921, 1998.

4. Cornelisse CJ, Cornelis RS and Devilee P: Gene responsible for familial breast cancer. Pathol Res Pract 192: 684-693, 1996.

5. Cubie A: When is a STD not a STD? HPV and cervical cancer. Microbiol Today 30: 58-60, 2003.

6. Reichman RC: Human papillomaviruses. In: Harrison's Principles of Internal Medicine. Braunwald E, Fauci AS, Kasper DL, et al (eds). 15th edition, McGraw-Hill, New York, pp1118-1120, 2001.

7. Bosch FX and de Sanjose S: Chapter 1: Human papillomavirus and cervical cancer-burden and assessment of causality. J Natl Cancer Inst Monogr 31: 3-13, 2003.

8. Walboomers JM, Jacobs MV, Manos MM, Bosch FX, Kummer JA, Shah KV, Snijders PJ, Peto J, Meijer CJ and Munoz N: Human papillomavirus is a necessary cause of invasive cervical cancer worldwide. J Pathol 189: 12-19, 1999.

9. Band V, Zajchowski D, Kulesa V and Sager R: Human papillomavirus DNAs immortalize normal human mammary epithelia cells and reduce their growth factor requirements. Proc Natl Acad Sci USA 87: 463-467, 1990.

10. Di Lonardo A, Venuti A and Marcante ML: Human papillomavirus in breast cancer. Breast Cancer Res Treat 21: 95-100, 1992.

11. Damin APS, Karam R, Zettler CG, Caleffi M and Alexandre COP: Evidence for an association of human papillomavirus and breast carcinomas. Breast Cancer Res Treat 84: 131-137, 2004.

12. Yu Y, Morimoto T, Sasa M, Okazaki K, Harada Y, Fujiwara T, Irie Y, Takahashi E, Tanigami A and Izumi K: HPV33 DNA in premalignant and malignant breast lesions in Chinese and Japanese populations. Anticancer Res 19: 5057-5061, 1999.

13. Yu Y, Morimoto T, Sasa M, Okazaki K, Harada Y, Fujiwara T, Irie Y, Takahashi E, Tanigami A and Izumi K: Human papillomavirus type 33 DNA in breast cancers in Chinese. Breast Cancer 7: 33-36, 2000. 
14. Kroupis C, Markou A, Vourlidis N, Dionyssiou-Asteriou A and Lianidou ES: Presence of high-risk human papillomavirus sequences in breast cancer tissues and association with histopathological characteristics. Clin Biochem 39: 727-731, 2006.

15. Kan CY, Iacopetta BJ, Lawson JS and Whitaker NJ: Identification of human papillomavirus DNA gene sequences in human breast cancer. Br J Cancer 93: 946-948, 2005.

16. Hennig EM, Suo Z, Thoresen S, Holm R, Kvinnsland S and Nesland JM: Human papillomavirus 16 in breast cancer of women treated for high grade cervical intraepithelial neoplasia (CIN III). Breast Cancer Res Treat 53: 121-135, 1999.

17. Widschwendter A, Brunhuber T, Wiedemair A, Mueller-Holzner E and Marth C: Detection of human papillomavirus DNA in breast cancer patients with cervical cancer history. J Clin Virol 31: 292-297, 2004.

18. Bratthauer GL, Tavassoli FA and O'Leary TJ: Etiology of breast carcinomas: no apparent role for papillomavirus types 6/11/ 16/18. Pathol Res Pract 188: 384-386, 1992.

19. Wrede D, Luqmani YA, Coombes KH and Vousden KH: Absence of HPV 16 and 18 DNA in breast cancer. Br J Cancer 65: 891-894, 1992.

20. Gopalkrishna V, Singh UR, Sodhani SP, Sharma JK, Hedau ST, Mandal AK and Das BC: Absence of human papillomavirus DNA in breast cancer as revealed by polymerase chain reaction. Breast Cancer Res Treat 39: 197-202, 1996.

21. Lindel K, Forster A, Altermatt HJ, Greiner R and Gruber G: Breast cancer and human papillomavirus (HPV) infection: no evidence of a viral etiology in a group of Swiss women. Breast 16: 172-177, 2007.

22. De Cremoux P, Thioux M, Lebigot I, Sigal-Zafrani B, Salmon R and Sestri-Garau X, for the Institut Curie Breast Group: No evidence of human papillomavirus sequences in invasive breast carcinoma. Breast Cancer Res Treat 109: 55-58, 2007.
23. De Villiers E-M, Sandstrom RE, zur Hausen H and Buck CE Presence of papillomavirus sequence in condylomatous lesions of the mammillae and in invasive carcinoma of the breast. Breast Cancer Res Treat 7: R1-R11, 2005.

24. Gumus M, Yumuk PF, Salepci T, Aliustaoglu M, Dane F, Ekenel M, Basaran G, Kaya H, Barisik N and Turhal NS: HPV DNA frequency and subset analysis in human breast cancer patients' normal and tumoral tissue samples. J Exp Clin Cancer Res 25: 515-521, 2006.

25. Sotlar K, Diemer D, Dethleffs A, Hack Y, Stubner A, Vollmer N, Menton S, Menton M, Dietz K, Wallwiener D, Kandolf R and Bultmann B: Detection and typing of human papillomavirus by E6 nested multiplex PCR. J Clin Microbiol 42: 3176-3184, 2004.

26. Medina D: Preneoplastic lesions in murine mammary cancers. Cancer Res 36: 2589-2595, 1996.

27. Dickson C: Role of the Int-genes in murine mammary tumor development and implications for human breast cancer. Int $\mathbf{J}$ Cancer 5: 51-54, 1990.

28. Wang Y, Pelisson I, Melana SM, Go V, Holland JF and Pogo BG: MMTV-like env gene sequences in human breast cancer. Arch Virol 146: 171-176, 2001.

29. Zangen R, Harden S, Cohen D, Parrella P and Sidransky D: Mouse mammary tumor-like env gene as a molecular marker for breast cancer? Int J Cancer 102: 302-307, 2002.

30. IARC (WHO): Monographs on the evaluation of carcinogenesis risk to human. Human papillomaviruses. Vol. 64. International Agency for Research on Cancer Scientific Publications, Lyon, 1992.

31. Manavi M, Baghstanian M, Kucera E, Berger A, Schatten C, Pischinger K and Czerwenka K: Papillomavirus and c-erbB-2 expression in diseases of the mammary nipple. Anticancer Res 21: 797-801, 2001. 